\title{
Evaluation of the Management Information System at the Primary Health Care in the National Health Insurance Program in Surakarta
}

\author{
Astri Sri Wariyanti'), Arief Suryono², Dono Indarto3) \\ ${ }^{1)}$ School of Health and Sciences Mitra Husada, Karanganyar, Surakarta \\ 2)Faculty of Law, Universitas Sebelas Maret, Surakarta \\ 3)Faculty of Medicine, Universitas Sebelas Maret, Surakarta
}

\begin{abstract}
Background: Management information system are intended to facilitate National Health Insurance (EXAMINATION ROOMKesehatan). This study aimed to evaluate theevaluation of themanagement information system so-called Primary Care (PCare) at the primary health care in the national health insurance program in Surakarta.

Subjects and Method: This was a descriptive-qualitative study. This was carried out in four selected community health center in Surakarta in August-November 2016. The data was collected with observation and in-depth interviews, documentation, and triangulation. The data was analyzed by data reduction,presentation, and conclusion.

Results: The application of PCarein Surakarta facilitated patient service. But there were someobstacle and error in the implementation of Pcare.

Conclusion: Pcare in Surakarta does not run optimally.But PCare facilitate service to patients and reporting system atEXAMINATION ROOM Surakarta.
\end{abstract}

Keywords: information systems, community health centers, primary care social, healthcare security

\section{Correspondence:}

Astri Sri Wariyanti.School of Health and SciencesMitraHusada, Karanganyar, Surakarta.Email: astri_new89@yahoo.com

\section{BACKGROUND}

$\overline{\text { Every implementation of the health system }}$ must have an information system (SI) to support the health management $(\mathrm{MOH}$, 2012). To improve health services to its customers, examination room Health introduces Primary Care (PCare) applications for Primary Health Facilities. The implementation of PCare has covered all regions in Indonesia. The number of health centers in Indonesia in April 2016 was 9,705 health facilities and health centers in the Surakarta City Health Office area had implemented PCare starting in 2015. The health center was the one that had implemented data integration (bridging) between PCare and the health centerManagement Infor- mation System (SIMPUS) at most beginning in the Surakarta region, namely in October 2015 for about 17 health centers.

This study aimed to evaluate the evaluation of the management information system so-called Primary Care (PCare) at the primary health care in the national health insurance program in Surakarta.

\section{SUBJECTS ANDMETHOD}

This wasa descriptive qualitativestudy conducted at Gilingan, Kratonan, Gajahan, and Pajang community health centers,from August to October 2016.

The subject of the study included the registration officer, the reporting department, and the medical personnel (doctors) 
who handled the patients, as well as the $\mathrm{Su}-$ rakarta examination roomHealth Officer. While the object is the PCA Health examination room Management Information System in Surakarta Health Center.

The sample size that the researchers wanted was 4 health centers with a calculation of $25 \%$ of the total health centers in $\mathrm{Su}-$ rakarta which is for about 7 health centers. The sampling method used was Quota Sampling technique.

This study instrument includes researchers, notebook, and mobile phone.
While the method of collecting data is nonparticipant observation, in-depth interviews, documentation, and triangulation.

The data analysis includes data reduction, data presentation, and conclusion drawing.

\section{RESULTS}

\section{Characteristics of Surakarta health center employees}

a. Number of outpatient health center staff Table 1 shows the number of outpatient health center staff.

Table 1. Number of outpatient health center staff

\begin{tabular}{lcccc}
\hline \multicolumn{1}{c}{ Position } & $\begin{array}{c}\text { Gilingan Health } \\
\text { Center }\end{array}$ & Age (year) & $\begin{array}{c}\text { Kratonan } \\
\text { health center }\end{array}$ & Age (year) \\
\hline The head ofhealth center & 1 person & 48 & 1 person & 50 \\
General practitioner & 1 person & 34 & 1 person & 40 \\
Dentist & 1 person & 37 & 1 person & 39 \\
Midwife & 4 people & 36 & 5 people & 33 \\
Nurse & 5 people & 34 & 6 people & 36 \\
Dental nurse & 1 person & 26 & 1 person & 39 \\
Staff & 8 people & 46 & 6 people & 47 \\
Nutritionist & - & - & 1 person & 37 \\
\hline
\end{tabular}

b. Hospitalized and inpatient health center

Table 2.Number of inpatient health center staff

\begin{tabular}{lcccc}
\hline \multicolumn{1}{c}{ Position } & $\begin{array}{c}\text { Gajahan } \\
\text { Health } \\
\text { center }\end{array}$ & Age (year) & $\begin{array}{c}\text { Pajang health } \\
\text { center }\end{array}$ & Age (year) \\
\hline The head ofhealth center & 1 person & 51 & 1 person & 49 \\
General practitioner & 4 people & 36 & 4 people & 35 \\
Dentist & 1 person & 35 & 2 people & 34 \\
Midwife & 12 people & 35 & 9 people & 36 \\
Nurse & 11 people & 34 & 10 people & 35 \\
Dental nurse & 1 person & 35 & 1 person & 28 \\
General Staff & 8 people & 48 & 10 people & 47 \\
Nutritionist & 1 person & 47 & 1 person & 41 \\
Health promotion & - & - & 2 people & 35 \\
Medical record & 1 person & 44 & 1 person & $\mathbf{2 2}$ \\
\hline
\end{tabular}

\section{How to entry a PCare Registration}

The registration method used in Surakarta Health Center is done using a computer with the SIMPUS (Puskesmas Management Information System) application where the data are automatically integrated (bridging) with the PCare application so that the data input process is done once.
SIMPUS registration data includes:

a. Type of visit (Outpatient)

b. Illness visit (general/examination room)

c. Number of medical record dan citizen number

d. Number ofexamination room

e. Name of the family head

f. Name of the patient 
g. Birthday

h. Type of visit

i. Gender

j. Address

\section{How to entry PCare Service}

PCare service entry is carried out by doctors, but the method of entry is different. Gajahanand Kratonan health center using PCare in the data entry, while the UPTD of Gilingan health center and Pajang health center use SIMPUS.

The way to enter the services with the PCare application in the Surakarta Health Center is presented as follows:

a. Patients who have registered wait in front of the intended examination room.

b. Patients get services according to the queue number from the examination room.

c. The doctor checks the patient and then inputs the PCare application. The doctor /nurse fills in the complaint items, therapy / medication, diagnosis, disease code, physical examination, blood pressure, treating medical personnel, and return status.

d. If the patient is referred, it will automatically display the name of the referral hospital with a referral number that can be seen in the referral hospital.

\section{Information generated by PCare}

a. A report on the number of patients examined per period.

b. Report on the number of capitation patients (general and dental outpatients).

c. Reports on the number of non-capitation patients include first-level inpatients, ANC, PNC, KB, laboratories, and use of ambulances

d. Report on the top 10 diseases per period.

e. Report on the number of patients referred.

f. Report on the management program of chronic diseases (DM and hypertension).
5. The Success Factors of the PCare of the Surakarta Health Center

a. Stable internet access.

b. Filling of PCare data is better because officers only input once.

c. Data automatically inputted will be immediately visible from the examination roomso that it is easy to communicate, monitor and evaluate.

d. Data inputted from the PCare application can be useful information and reports for the health center or examination room.

6. Barriers to PCare in Surakarta Health Center

a. Power failure.

b. Patients' data recorded in SIMPUS sometimes cannot be opened at examination roomso officers only enter PCare. This causes data to be incomplete.

c. The complaint data column in SIMPUS cannot be filled.

d. PCare errors when there are patients who must be referred, even though there must be a reference number from examination roomto be able to refer.

\section{Monitoring and Evaluation of the} Surakarta examination roomHealth Branch

Monitoring conducted by the Health examination room Surakarta Branch is always carried out every day because each Surakarta City Health Center enters the patient's data on PCare and will be immediately seen by the Surakarta examination room Health Branch through a computer through the PCare application.

The evaluation is carried out periodically every once a month and every month the health center submits the hard file to the Surakarta branch of the Health examination room. 
Journal of Health Policy and Management (2016), 1(1): 53-60

https://doi.org/10.26911/thejhpm.2016.01.01.08

\section{DISCUSSIONS}

\section{Characteristics of Surakarta health center employees}

The number of employees at the UPTD Gilingan Health Center associated with PCare users was 21 people and the UPTD Kratonan health centerconsisted of 22 people, while the number of staff at the UPTD Gajahan health center was related to PCare users for about 40 people and the UPTD Pajang health center for about 41 people.

Registration staff at the health centers in Surakarta are on average more than 45 years old except UPTD Gajahan health centerin which one of them is 44-year-old registration officer and Pajang health center which is one of them is 22-year-old registration officer with a Diploma in Medical Record. This affects the process of registering and entering data into communication.

From the average observation results, the registration process is longer than the minimum service standard based on KEPMENKES RI/129/MenKes/SK/II/2Oo8, namely the registration time is less than 2 minutes. In the digital era that demands institutions not to mention the health center to carry out computerized services is a little difficult for officers in terms of registration speed.

\section{Pcare registration method}

Outpatient registration services at the Surakarta City Health Center used MIS which has been integrated with P-Care so that officers only enter the MIS once and then they would be automatically listed on PCare.

The data filled in PCare was in accordance with Siallagan (2014), which stated that the data that must be filled in the PCare registration section include Type of Participant, Type of Card, Name, Status of Participants, Date of Birth, Gender, and Participant's KDP.

\section{Pcare service method}

Patients who have registered in the registration section would receive the services at $\mathrm{TC}$, which were general examination room, teeth TC, and MCH TC. Medical officers enter the data through MIS and PCare.

MIS in Surakarta health center has been integrated with PCare, but if the complaint item cannot be filled in MIS so that the officer manually enter the PCare and MIS, the officer must enter the items by two times which could cause some items in MIS and PCare connot be filled. If the SIMPUS was filled, the complaint item in PCare was not filled because the MIS application complaint menu cannot be filled. If the PCare was filled in, the items in MIS were not filled because sometimes the patient's registration data cannot be opened in MIS poly.

\section{Information produced by Pcare}

The Health Center of Surakarta as the first level health service which provided basic services either outpatient or inpatient, which in turn would produce a report that would be reported to the Health NHIP Branch of Surakarta every month on the maximum of 10. This was according to $\mathrm{Mi}$ nister of Health Regulation No. 71/2013 concerning Health Services on National Health Insurance that health facilities were required to report health service activities that were given regularly in every month to Health NHIP.

One of the reports sent was a non-capitation report that included a claim submission form which the format was provided by Health NHIP. Usually, the Health NHIP of Surakarta Branch would make a claim payment for 5 to 7 days after the file was fully received. If the claim documents were incomplete, the Surakarta Branch Health NHIP cannot make a claim payment. Of the four puskesmas studied, only the Gilingan Health Center UPTD which 
had ever been denied a claim, which was the ANC service because the conditions were incomplete, so that the Gilingan Health Center UPTD paid independently.

\section{The success factors of the PCare in Surakarta health center.}

a. Stable internet access

One of the factors of PCare's success was stable internet access. Surakarta is a big city, so the Internet in the community health center has never experienced problems.

b. Better data fulfillment

The Surakarta Health Center has implemented a bridging system which was integrated data between MIS and PCare. This could alleviate the burden on officers because officers had to input twice before, in addition to lengthening the registration and service time as well as the data written to be incomplete. However, because it has been integrated, it could speed up data entry and the data completeness became more complete.

c. PCare data was immediately seen on Health NHIP computers

PCare data was immediately seen on Health NHIP computers so that it was easy to monitor and evaluate the data that was entered from the Surakarta Health Center to appear at the Surakarta NHIP Health Office, for example the number of NHIP patients examined on that day, inpatients, and referral patients. So, if the NHIP needed the data related to services at the health center, then there was no need to come to the health center or send a soft copy but it can be accessed immediately.

In addition, if the community health center wanted to refer the patients but the PCare experienced errors, they would call the Surakarta Health NHIP and they would immediately get a referral number. This communication was very important to be carried out between health facilities and
NHIP so that the services could always run quickly for the sake of the patients.

d. Pcare data would be a useful informations and reports

The data from the registration process and health center services would produce the reports that would be sent to the Surakarta Health NHIP. The system in PCare has immediately saved the data, therefore, if the officers reported the number of patients per day or per month, they have to click on the report menu and select the number of patients, and then select for day or month. After that, it was printed and ready to be sent to the Surakarta Health NHIP. In addition, it was also useful for health center, for example to find out the number of patients in a day and the highest cases of illness that would be used as an evaluation material for improving services and providing medicine.

\section{The Contraints of Pcare in Sura- karta Health Center}

a. Power Failure

The constraints faced by law enforcement officers and patient services were when the electricity was off, while the patient's service must be continued.

If there was a power failure and the patient was still registered, the officer would write manually in the register book and the patient was still allowed to wait at TC to get the service. Meanwhile, the medical officer would record the patient's condition in the medical record document and record it in his/her own sheet so that if the electricity has been turned on, it would be inputted after the service was finished.

b. The MIS data cannot be opened in TC The UPTD of Gajahan Health Center and Kratonan Health Center used the PCare because the data of the patients in MIS cannot be displayed at TC so that the medical officer only entered the PCare. This happened because the Internet connection in the in- 
Journal of Health Policy and Management (2016), 1(1): 53-60

https://doi.org/10.26911/thejhpm.2016.01.01.08

ternal health center from TC registration was sometimes unstable so that the MIS data cannot be seen on TC. This condition could lead to the incompleteness of data fulfillment. This was not in accordance with the Ministry of Health of the Republic of Indonesia (2006), that medical record data must be filled in completely because it could be used as a reference for subsequent patients, especially if the patient was doing another treatment.

c. The MIS complaint data column cannot be filled

The UPTD of Gilingan Health Center and Pajang Health Center used MIS in the patient services data input. The problem was that the complaint column at MIS cannot be filled, even though the data was integrated with PCare so that the complaint column in the PCare became empty. In fact, socialization has been held about filling in medical record data including electronic data such as MIS and Pcare, however, because the socialization was not carried out periodically and there was a lack of human resources, the completeness of filling in the data still cannot be maximized.

d. PCare error and patients are referred Another obstacle from PCare was the PCare experienced error in the service process and patients were required to be referred so that it would prolong the service because if the patient was referred, there would be a referral number from the NHIP. The thing that must be done was to register via cellphone, but if the internet was not stable and the process took a long time, then the health center would confirm to the Surakarta Health NHIP. After that, Health NHIP would suggest to refer the patients first and the data would be inputted if the PCare was normal.

\section{Monitoring and Evaluation of Health NHIP in Surakarta}

Monitoring was always done easily without having to come to the primary health facility. With the PCare, the data of patients entering primary health facilities would immediately be seen in Health NHIP of Surakarta through a computer so that it was easy to control.

While the evaluation was carried out after getting monthly reports from primary health facilities or Surakarta Health Center by 17 health centers. For example, a report on the number of patients who came to health center, the number of capitation, non-capitation, referral, prolanis, and the top 10 of the diseases would be used as a benchmark of participation and also the NHIP in collaboration with primary health facilities. In addition, it could become an input for management and subsequent planning.

REFERENCE

Health Officeof Surakarta City (2016). Cara pengaplikasian SIMPUS di Puskesmas Kota Surakarta (How to apply SIMPUS in Surakarta City Health Center).

Ministry of Health of the Republic of Indonesia(2014). Peraturan badan penyelenggara jaminan sosial kesehatan nomor 1 tahun 2014 tentang penyelenggaran jaminan kesehatan (Regulation governing body of social Security provider Number 1 year 2014 about health insurance). retrieved from https://bpjs-kesehatan.go.id/bpjs/dmdocuments/ab9fd674ef101c1445c7a 4cfcdc7cf4e.pdf

Rismawati(2015). Pelayanan examination roomkesehatan masyarakat di Puskesmas Karang Asam Kecamatan Sungai Kunjang Kota Samarinda (Public health examination room service in Puskesmas Karang Asam District 
Sungai Kunjang City Samarinda). eJournal Ilmu Administrasi Negara. 3(5): 1668-1682. Retrieved from https://ejournal.an.fisip-unmul.ac.id/site $/ \mathrm{p}=1586$

Siallagan T (2014). Penggunaan data dalam mendukung pelayanan kesehatan (Data use in supporting healthcare). Retrieved from https://www.bappenas.go.id/files/4814/1290/5877/03_ PENGGUNAAN_DATA_DALAM_M ENDUKUNG_PELAYANAN_KESEH ATAN.pdf

Ulfatin N (2015). Metode penelitian kualitatif di bidang pendidikan: Teori dan aplikasinya (Qualitative research methods in education: Theory and application). Malang: Media Nusa Kreatif.
WHO (2000). The world health report 2000 health system: Improving performance. France: WHO Graphics.

Wilper AP, Woolhandler S, Lasser, KE, McCormick D, Bor, DH, Himmelstein DU (2009). Health Insurance and Mortality in US Adult. AmJPublic Health. 99(12): 2289-2295.doi10.2105/AJPH.2008.157685

Yanrizal, Anita B, Suryani D (2013). Analisis kebijakan jaminan kesehatan Kota Bengkulu dalam upaya efisiensi dan efektivitas pelayanan di puskesmas (Analysis of the health insurance policy of Bengkulu in the effort to efficiency and effectiveness of service in public health center). Jurnal Kebijakan Kesehatan Indonesia. 02(01): 151-160.Retrieved from https://journal.ugm.ac.id/jkki/article/view/3213 